\title{
Penanganan Guru PAUD Terhadap Kecemasan Berpisah Pada Anak di Sekolah
}

\author{
Prinda Kartika Mayang Ambari \\ Fakultas Psikologi Universitas Surabaya \\ prindakartika@gmail.com \\ Lena Nesyana Panjaitan \\ Fakultas Psikologi Universitas Surabaya \\ lenapanjaitan66@gmail.com \\ Aniva Kartika \\ Fakultas Psikologi Universitas Surabaya \\ anivakartika@gmail.com
}

\begin{abstract}
Separation anxiety can occur to anyone, including children. Children who are in a new situation or environment that makes them separate from sticking figures can experience separation anxiety. Factors that cause separation anxiety according to Moldovan \& Moldovan (2013) are genetic and environmental. Separation anxiety is often reported to occur at school. This requires treatment as soon as possible so as not to develop into a disorder. This research was conducted to see how the picture of children experiencing anxiety separated at school and the handling done by the teacher at school. Subjects in the study were 4 teachers who teach in PAUD. Data collection methods through interviews, observations, and separation questionnaires anxiety. The technique used by researchers in selecting study participants is the purposive sampling method. The results of the study show that the treatment has not shown maximum results. $n$ the separation experienced by children in schools on average is still high.
\end{abstract}

Keywords: separation anxiety; teacher handling; PAUD

\begin{abstract}
Abstrak
Kecemasan berpisah dapat terjadi pada siapapun termasuk pada anak-anak. Anak yang berada pada situasi atau lingkungan baru yang membuat terpisah dari figur lekat dapat mengalami kecemasan berpisah. Faktor-faktor yang menyebabkan kecemasan berpisah menurut Moldovan \& Moldovan (2013) adalah genetik dan lingkungan. Kecemasan berpisah sering dilaporkan terjadi di sekolah. Hal ini membutuhkan penanganan sesegera mungkin supaya tidak berkembang menjadi suatu gangguan. Penelitian ini dilakukan untuk melihat bagaimana gambaran anak yang mengalami kecemasan berpisah di sekolah dan penanganan yang dilakukan guru selama ini di sekolah. Subjek dalam penelitian adalah 4 orang guru yang
\end{abstract}


mengajar di PAUD. Metode pengumpulan data melalui wawancara, observasi dan kuesioner kecemasan berpisah.Teknik yang dilakukan peneliti dalam memilih partisipan penelitian adalah dengan purposive sampling method. Hasil penelitian menunjukkan bahwa penanganan yang dilakukan belum menunjukkan hasil yang maksimal. Gejala kecemasan berpisah yang dialami oleh anak di sekolah rata-rata masih tinggi.

Kata kunci : kecemasan berpisah, penanganan guru, PAUD

\section{Pendahuluan}

Dalam kehidupan sehari-hari, seseorang dapat mengalami peristiwa yang dapat menimbulkan kecemasan. Kecemasan merupakan keadaan yang sering dialami oleh setiap individu dan merupakan suatu proses yang wajar (Albano, 2002). Sadock (2015) menjelaskan bahwa kecemasan adalah respon terhadap situasi tertentu yang mengancam dan merupakan hal yang normal terjadi menyertai perkembangan, perubahan, pengalaman baru atau yang belum pernah dilakukan, serta dalam menemukan identitas diri dan arti hidup. Kecemasan adalah kekhawatiran atas masalah yang diantisipasi (Davison \& Neale, 2012). Seperti halnya Albano (2002), Davison \& Neale (2012) juga menyebutkan bahwa kecemasan adalah suatu yang adaptif dalam membantu kita untuk mengantisipasi ancaman yang akan datang untuk menghindari situasi yang berpotensi menimbulkan bahaya.

Kecemasan dapat terjadi pada siapapun termasuk pada anakanak.Kecemasan dapat terjadi ketika anak berada pada situasi atau lingkungan yang baru.Pada saat tahun ajaran baru, anak-anak mulai masuk ke dalam lingkungan sekolah.Anak yang semula merasakan kenyamanan berada di lingkungan rumah, harus beradaptasi dengan lingkungan sekolah dan terpisah dari figur lekatnya.Kecemasan yang muncul dari peristiwa tersebut salah satunya adalah kecemasan berpisah (Schneider, Kossowsky \& Wilhelm, 2013).Kecemasan berpisah paling banyak dilaporkan memiliki gejala distress separation-related, menghindar untuk tidur terpisah dengan pengasuh atau orangtua di rumah (Schneider, Kossowsky \& Wilhelm, 2013).Kecemasan berpisah banyak dialami oleh anak-anak usia dini. Penelitian yang dilakukan oleh Schneider dkk (2013) 
meneliti 49 anak yang mengalami kecemasan berpisah. Sedangkan penelitian yang dilakukan di Sydney Australia oleh Momartin, Manicavasagar, Silove, Rapee dan Waters (2000) mengungkap bahwa 63\% anak usia dini mengalami kecemasan berpisah.

Berdasarkan permasalahan tersebut di atas dan banyaknya anak yang hingga saat ini masih mengalami kecemasan berpisah maka peneliti ingin meneliti lebih lanjut dan cara mengatasinya. Kecemasan berpisah berisiko besar pada tiga level usia yakni antara 5-6 tahun, 7-9 tahun, dan 12-14 tahun, mendekati kira-kira 40\% dari jumlah anak (Moldovan \& Moldovan, 2013). Di Indonesia sendiri, penelitian mengenai kecemasan berpisah di sekolah ditunjukkan dari data penanganan kasus dari Klinik Terpadu Fakultas Psikologi UI pada bulan Juli 2009 - 2012 yaitu 0,73\%. Persentase yang sedikit ini menunjukkan bahwa masih ada anak yang mengalami kecemasan berpisah dan perlu untuk diberikan penanganan.

Kecemasan berpisah diartikan sebagai salah satu bentuk kecemasan yaitu anak meninggalkan rumah (keluarga) untuk bersama dengan teman di sekolah (orang asing) (Hasanah, 2013).Hal tersebut dimanifestasikan dengan perasaan takut yang hebat (Moldovan \& Moldovan, 2013). Kecemasan berpisah dianggap normal hingga usia 2 tahun dan setelah itu biasanya anak mulai membawa diri pada situasi dan orang baru, dan rasa takut mulai berkurang (Erikson, 1985 dalam Moldovan \& Moldovan, 2013).Kecemasan berpisah yang berlangsung secara terus-menerus maka dapat berkembang menjadi suatu gangguan (Sadock, 2015).Anak dengan kecemasan berpisah ketika berpisah dengan figur lekat memiliki manifestasi seperti isolasi sosial, kesedihan, kesulitan berkonsentrasi, takut pada binatang dan kegelapan (Galbard, 2007 dalam Moldovan \& Moldovan, 2013).Schaffer (2005 dalam Moldovan \& Moldovan, 2013) juga menyebutkan bahwa kecemasan berpisah dapat juga dimanifestasikan dalam gejala psikologis, kognitif, emosional dan behavioral.

Faktor-faktor seperti genetik dan lingkungan dapat menyebabkan seseorang mengalami kecemasan berpisah (Moldovan \& Moldovan, 2013). Hasanah (2013) menambahkan faktor lain yang juga menjadi peneyebab antara 
lain hubungan kelekatan yang tidak aman, terjadi transisi dalam lingkungan yakni dari rumah ke sekolah, serta pengalaman keluarga yang negatif (Chorpita, 2001 dalam Hasanah, 2013). Schneider, Rapee, Dubi, In-Albon(2009) menyebutkan kecemasan berpisah dapat disebabkan juga oleh adanya distorsi kognitif yang menghasilkan perilaku maladaptif

Perpisahan anak dengan figur lekat dalam waktu yang cukup lama untuk mengikuti kegiatan pembelajaran di dalam kelas menimbulkan adanya kecemasan. Permasalahan muncul ketika kecemasan yang dialami anak masih ada setelah melewati masa adaptasi yaitu empat minggu pertama pembelajaran di kelas. Hal tersebut seringkali menjadi alasan munculnya penolakan anak untuk pergi ke sekolah (Dabkwoska, 2011) serta reaksi lainnya seperti meminta figur lekat untuk menemani di dalam kelas, menolak dengan menarik atau bahkan menangis apabila figur lekat akan pergi ke luar kelas.

Kejadian seperti di atas tentunya dapat memberikan dampak negatif kepada anak. Hasanah (2013) menjelaskan bahwa anak dengan kecemasan berpisah selalu ingin untuk bersama dengan figur lekatnya untuk mendapatkan cinta dan dukungan atas apapaun yang dilakukannya, sehingga ketidakhadiran figur lekat akan membuat anak menolak untuk terlibat dalam pembelajaran di dalam kelas saat anak bersekolah. Keterlibatan yang rendah dalam proses pembelajaran di kelas yang disebabkan oleh kecemasan berpisah pada akhirnya akan berpengaruh pada pendidikan anak dan kemandirian anak sehingga sesegera mungkin perlu ditangani.

Kecemasan berpisah berdampak pada ketidakmandirian anak menyelesaikan tugas akademik dan menjalankan fungsi sosialnya (Hasanah, 2013).Heath (2004 dalam Peleg, Halaby \& Whaby, 2006) menyebutkan bahwa kecemasan berpisah dapat menyebabkan berbagai masalah seperti rendahnya prestasi akademik, hubungan sosial dan kesulitan penyesuaian emosi. PAUD Xjuga menyebutkan salah satu dampak negatif dari anak yang mengalami kecemasan berpisah adalah tidak bisanya menyesuaikan diri dengan baik sehingga berakibat pula pada konsentrasi belajar di kelas. 
Berbagai cara telah dilakukan oleh pihak guru-guru PAUD X mulai dari memberi pengertian, mendampingi anak selama proses mengajar, meminta anak berangkat sekolah lebih awal dan memberikan reward. Akan tetapi, upaya tersebut nampaknya kurang berhasil dan terjadi aksi mogok dari anak yang bersangkutan karena merasa takut bila ditinggal di sekolah sendiri.Keterampilan dan pengetahuan yang kurang membuat guru menjadi mudah panik ketika menghadapi anak dengan kecemasan berpisah yang menangis dan tantrum.Selain itu, karena merasa kesulitan yang terjadi adalah pembiaran pada perilaku anak di dalam kelas (tidak mau atau menyelesaikan tugas yang diberikan).Guru juga menjadi kurang memberikan perhatian dan melibatkan anak pada pembelajaran di kelas.Selain pengetahuan dan keterampilan dalam mengatasi anak dengan kecemasan berpisah, guru juga memerlukan keterampilan dalam menghadapi wali murid.

Intervensi psikologis perlu dilakukan guna mengatasi permasalahan kecemasan berpisah pada anak PAUD. Selain berdampak pada kemandirian, fungsi sosial dan prestasi akademik pada anak, kecemasan berpisah yang tidak segera ditangani akan berkembang menjadi suatu gangguan. Apabila sudah menjadi suatu gangguan, lebih lanjut lagi kecemasan berpisah dapat mengakibatkan perkembangan gejala gangguan mental lainnya.Studi longitudinal menunjukkan anak dengan gangguan kecemasan berpisah dapat beresiko pada gangguan kecemasan lainnya yaitu panic disorder atau agoraphobia pada saat dewasa (Biederman, 2005 dalam Figueroa, 2012).

Penelitian-penelitian sebelumnya menunjukkan bahwa Intervensi psikologi yang dilakukan dapat menurunkan tingkat kecemasan berpisah pada anak.Intervensi tersebut langsung dilakukan pada anak yang bersangkutan.Padahal, setiap tahun ajaran baru di sekolah masih saja ditemui anak dengan kecemasan berpisah.Permasalahan-permasalahan sebagai dampak dari kecemasan berpisah yang dialami anak kembali muncul.Guru yang menangani langsung anak tersebut kewalahan karena tidak dibekali dengan pengetahuan dan keterampilan yang baik.Menilik dari kejadian yang berulang tersebut maka guru memerlukan suatu pedoman untuk mengatasi kecemasan berpisah.Guru 
diharapkan dapat meningkatkan pemahaman dan keterampilan dalam mengatasi anak dengan kecemasan berpisah sehingga kedepannya ketika menemui kasus serupa, guru dapat sesegera mungkin memberikan pendampingan.

\section{Tujuan Penelitian}

Berdasarkan rumusan masalah di atas, maka tujuan dari penelitian ini adalah:

a. Melihat gambaran siswa yang mengalami kecemasan berpisah di sekolah.

b. Mengetahui penanganan yang dilakukan guru selama ini terhadap siswanya yang mengalami kecemasan berpisah di sekolah.

\section{Manfaat Penelitian}

a. Teoritis

Penelitian ini memberikan sumbangan pengetahuan dan menambah kekayaan ilmu psikologi, khususnya psikologi pendidikan.

b. Praktis

1) Bagi guru; Penelitian ini memberikan pengetahuan dan pemahaman mengenai kecemasan berpisah berpisah di sekolah.

2) Bagi praktisi psikologi; Penelitian ini memberikan gambaran kepada praktisi psikologi mengenai gambaran anak yang mengalami kecemasan berpisah dan penanganan yang diberikan.

3) Bagianak dengan kecemasan berpisah; Guru yang memiliki pengetahuan dan pemahaman yang baik dapat membantu anak yang mengalami kecemasan berpisah dalam meningkatkan keberfungsian sebagai individu (kemandirian).

4) BagiOrangtua yang memiliki anak dengan kecemasan berpisah; Penelitian ini memberikan pengetahuan mengenai penyebab dan dampak anak mengalami kecemasan sehingga dapat membantu memutuskan tindakan apayang harus dilakukan, memahami kebutuhannya dan merawat anak tersebut nantinya. 


\section{Metode}

Teknik yang dilakukan peneliti dalam memilih partisipan penelitian ini adalah dengan purposive sampling method.Teknik yang menentukan sampel dengan pertimbangan tertentu (Sugiyono, 2015). Adapun partisipan yang dipilih adalah empat guru PAUD dengan kriteria antara lain : (1) pendidikan terakhir S1, (2) terdaftar sebagai guru di sekolah PAUD, (3) memiliki siswa yang mengalami kecemasan berpisah sesuai dengan kriteria DSM Vdalam kelas yang diajar

Peneliti kemudian melanjutkan dengan proses asesmen kepada subjek. Proses asesmen dilakukan dengan menggunakan metode wawancara dan observasi. Selain itu, peneliti juga menggunakan kuesioner kecemasan berpisah untuk mengindentifikasi anak yang mengalami kecemasan berpisah di sekolah.Wawancara dilakukan secara mendalam kepada guru yang bertujuan untuk menggali informasi terkait dengan kecemasan berpisah yang dialami oleh anak di sekolah.Selain itu untuk melihat kesulitan / hambatan yang dialami dan apa saja yang telah dilakukan untuk menangani anak dengan kecemasan berpisah. Data penelitian juga diperkuat dengan wawancara orangtua untuk melihat perbandingan perilaku kecemasan berpisah anak di rumah dan di sekolah. Wawancara dalam penelitian dilakukan secara semi terstruktur, yakni peneliti telah menyiapkan pertanyaan atau pedoman wawancara dan dapat mengembangkan pertanyaan sesuai dengan kebutuhan.Wawancara selain dilakukan kepada guru, juga dilakukan kepada orangtua anak yang bersangkutan.Aspek-aspek dalam pedoman wawancara yang disusun peneliti antara lain (1) Pengetahuan mengenai kecemasan berpisah yang meliputi definisi, gejala dan karakteristiknya, (2) Kesulitan / kendala yang dihadapi ketika mengangani anak dengan kecemasan berpisa, (3) Langkah-langkah apa saja yang telah dilakukan untuk mengatasi anak dengan kecemasan berpisah dan sejauh mana efektifitasnya, (4) Dampak dari kecemasan berpisah yang dialami anak di sekolah dan di rumah.

Observasi dalam penelitian ini menggunakan observasi natural yaitu observasi yang dilakukan pada situasi alamiah tanpa adanya manipulasi atau intervensi dari observer.Tujuan dari observasi natural adalam menggambarkan 
perilaku yang muncul pada situasi alamiah sehingga cenderung akurat (Listyo, 2012). Observasi dilakukan kepada subjek untuk melihat bagaimana subjek menangani anak dengan kecemasan berpisah di sekolah. Adapun pedoman yang digunakan untuk melakukan observasi pada guru antara lain (1) Sikap guru kepada anak dengan kecemasan berpisah saat masuk ke dalam kelas, (2) Sikap guru kepada anak dengan kecemasan berpisah ketika proses pembelajaran di dalam kelas, (3) Respon dan sikap guru ketika anak dengan kecemasan berpisah menolak mengikuti arahan / instruksi / tugas yang diberikan oleh guru, (3) Respon dan sikap guru ketika anak mulai menunjukkan gejala kecemasan berpisah di dalam kelas (menangis, tidak konsentrasi terhadap pembelajaran, mencari figur lekatnya, ingin meninggalkan kelas).

Seperti yang telah disebutkan diatas bahwa untuk menidentifikasi anak yang mengalami kecemasan berpisah di sekolah, peneliti menggunakan kuesioner kecemasan berpisah.Kuesioner kecemasan berpisah ini merupakan pengembangan dari Preschool Anxiety Scale (PAS) dan DSM V.Kuesioner yang diberikan terdiri dari dua versi yakni versi orangtua dan versi guru.Guru dan orangtua diminta membaca sejumlah pernyataan dan melingkari angka di kolom samping pernyataan yang menggambarkan diri anak. Mereka melingkari angka 0 jika pernyataan sama sekali tidak benar, 1 jika pernyataan jarang benar, 2 jika pernyaataan terkadang benar, 3 jika pernyataan cukup benar, dan 4 jika pernyataan seringkali benar.Analisis data pada tahap ini dilakukan dengan kualitatifmelalui hasil wawancara terhadap guru sebagai partisipan dan orangtua sebagai penunjang pengambilan data penelitian. Selanjutnya dilakukan analisa dengan melihat tema-tema atau pola permasalahan perilaku anak dengan kecemasan berpisah di sekolah. 


\section{Hasil dan Pembahasan}

Tabel 1 Data Partisipan

\begin{tabular}{lcccc}
\hline & Partisipan 1 & Partisipan 2 & Partisipan 3 & Partisipan 4 \\
\hline Nama (Inisial) & NU & LI & DI & RA \\
Jenis Kelamin & Perempuan & Perempuan & Perempuan & Perempuan \\
Tempat/Tanggal & Surabaya, & Surabaya, & Lamongan, & Sidoarjo, \\
Lahir & 22 November 1971 & 17 Maret 1981 & 13 Juli 1989 & 2 Februari 1993 \\
Pendidikan & S1 PG PAUD & S1 PG PAUD & S1 PG PAUD & S1 Psikologi \\
Suku Bangsa & Jawa & Madura & Jawa & Jawa \\
Latar Belakang & Jawa Timur & Madura & Jawa Timur & Jawa Timur \\
Budaya & Islam & Islam & Islam & Islam \\
Agama & Kawin & Belum Kawin & Kawin & Belum Kawin \\
Status Perkawinan & Guru TK & Guru TK & Guru TK & Guru TK \\
Pekerjaan & & & &
\end{tabular}

Dari kuesioner kecemasan berpisah yang diberikan kepada guru dan orangtua menunjukkan bahwa beberapa anak memiliki gejala kecemasan berpisah dan berada di kategori tinggi. Beberapa aitem juga memiliki skor tertinggi yakni 4 (sangat sering benar) yang artinya bahwa anak masih memiliki kecemasan yang tinggi terhadap perpisahan. Skor yang tinggi juga menunjukkan bahwa penanganan yang telah dilakukan oleh guru belum maksimal dan belum dapat mengatasi kecemasan berpisah yang dialami oleh anak.

Tabel 2 Persamaan dan Perbedaan Penangan Guru Terhadap Kecemasan Berpisah di Sekolah

\begin{tabular}{|c|c|c|c|c|}
\hline Penanganan Guru di Sekolah & $\begin{array}{c}\text { Partisipan } 1 \\
\text { (NU) }\end{array}$ & $\begin{array}{c}\text { Partisipan } 2 \\
\text { (LI) }\end{array}$ & $\begin{array}{c}\text { Partisipan } 3 \\
\text { (DI) }\end{array}$ & $\begin{array}{c}\text { Partisipan } 4 \\
\text { (RA) }\end{array}$ \\
\hline \multicolumn{5}{|l|}{ Dukungan Emosional } \\
\hline $\begin{array}{l}\text { 1. Memeluk anak yang menangis } \\
\text { karena tidak mau lepas dari figur } \\
\text { lekat selama pembelajaran di } \\
\text { kelas }\end{array}$ & $\checkmark$ & $\checkmark$ & $\checkmark$ & $\checkmark$ \\
\hline $\begin{array}{l}\text { 2. Memberikan stampel dan pujian } \\
\text { kepada anak ketika anak bersedia } \\
\text { melakukan apa yang diminta oleh } \\
\text { guru. }\end{array}$ & $\checkmark$ & $\checkmark$ & $\checkmark$ & $\checkmark$ \\
\hline $\begin{array}{l}\text { 3. Tidak memaksa anak ketika } \\
\text { menolak untuk mengikuti } \\
\text { kegiatan }\end{array}$ & $\checkmark$ & $\checkmark$ & $\checkmark$ & $\checkmark$ \\
\hline $\begin{array}{l}\text { 4. Merayu dan menyemangati anak } \\
\text { agar bersedia mengikuti kegiatan } \\
\text { di sekolah }\end{array}$ & $\checkmark$ & $\checkmark$ & $\checkmark$ & $\checkmark$ \\
\hline $\begin{array}{l}\text { 5. Memangku anak yang sedang } \\
\text { menangis }\end{array}$ & $\checkmark$ & - & $\checkmark$ & - \\
\hline \multicolumn{5}{|l|}{ Pembelajaran di kelas } \\
\hline 6. Aktif melibatkan anak dalam & $\checkmark$ & $\checkmark$ & - & - \\
\hline
\end{tabular}


kegiatan di dalam kelas

7. Kreatif mencari cara agar anak tertarik dan mengalihkan perhatian anak pada figur lekat

8. Memberikan instruksi berulang pada anak yang kesulitan mengerjakan tugas

9. Membantu dan mendampingi anak yang kesulitan mengerjakan tugas di kelas

| Pendekatan pada anak

10. Menyapa anak saat anak datang ke sekolah

11. Guru aktif bertanya menanyakan kebutuhan anak

12. Mengajaknya melakukan aktivitas bermain

13. Mengabaikan permintaan anak untuk pulang cepat

14. Melakukan home visit supaya lebih dekat dengan anak

| Melibatkan orangtua / orang lain

15. Mengajak orangtua untuk bekerja sama

16. Meminta bantuan figur lekat untuk membantu anak di dalam kelas

17. Mengandalkan figur lekat atau orang lain (helper) untuk memenuhi kebutuhan anak selama di sekolah

18. Meminta bantuan orang lain (helper) untuk mengawasi anak di dalam kelas ketika kewalahan menangani anak

19. Meminta bantuan anak lain untuk mengajak anak dengan kecemasan berpisah melakukan kegiatan bersama

20. Mengijinkan figur lekat menemani di dalam kelas

| Time Out

21. Melanjutkan dengan kegiatan lain ketika anak tetap menolak mengikuti kegiatan

22. Mengabaikan pertanyaan anak mengenai figur lekat

23. Membiarkan anak melakukan aktivitasnya sendiri

24. Mengabaikan tangisan anak

| Tindakan lain

25. Mengunci pintu kelas

26. Melakukan sedikit pemaksaan untuk memisahkan anak dari figur lekat 
Berdasarkan pemaparan diatas dapat dilihat bahwa guru sudah melakukan beberapa upaya penanganan dan pendampingan untuk mengatasi anak yang mengalami kecemasan berpisah di sekolah.Hal ini menunjukkan bahwa guru sudah menjalankan perannya sebagai orangtua yakni mewakili orangtua murid disekolah dalam mendidik dan melakukan tanggung jawabnya dalam membina kesehatan mental siswanya (Usman, 2002).Kecemasan berpisah merupakan permasalahan yang cukup sering terjadi pada siswa sehingga perlu sesegera mungkin untuk dapat ditangani dan mendapat perhatian supaya tidak berkembang menjadi suatu gangguan atau menimbulkan perkembangan gejala mental lainnya.

Dari penanganan yang telah dilakukan oleh gurubelum menunjukkan hasil yang maksimal.Anak masih mengalami gejala kecemasan berpisah di sekolah dan rata-rata masih tinggi.Hal ini terlihat dari hasil kuesioner kecemasan berpisah yang diisi oleh guru kelas dan orangtua dengan hasil skor tertinggi pada sebagian besar gejala kecemasan berpisah.Terlihat pada tabel diatas ada kecenderungan guru untuk membiarkan anak melakukan aktivitasnya sendiri atau malah mengandalkan figur lekat ketika menghadapi anak yang sulit.Padahal, anak yang tinggi tingkat kecemasannya membutuhkan lebih banyak pengarah / tuntunan (Kozier, 2011).Respon yang ditunjukkan ketika gejala kecemasan muncul adalah seperti mengeluh sakit kepala, berkeringat dan komunikasi verbal menjadi terganggu (Kozier, 2011).Selain itu, anak yang mengalami kecemasan tinggi seringkali mengkhawatirkan hal-hal yang tidak menyenangkan yang pada akhinrya membuat belajar di sekolah menjadi tidak efektif (Semiun, 2006).Kecemasan juga dapat mempengaruhi pemikiran, persepsi dan belajar (Sadock, 2015).Kecemasan dapat menyebabkan kebingungan dan distorsi persepsi. Distorsi persepsi pada akhirnya dapat menganggu proses belajar, menurunkan konsentrasi dan ingatan, merusak kemampuan individu dalam menghubungkan antara hal satu dengan lainnya (membuat asosiasi) (Sadock, 2015).Hal inilah yang membuat anak dengan kecemsan berpisah terganggu fungsinya (sosial, akademik) yang membuat hasil evaluasi pembelajaran menjadi kurang baik.Dalam kegiatan pembelajaran di kelas, anak membutuhkan instruksi 
yang diulang-ulang dan pendampingan ketika diberikan tugas atau perintah dari guru. Dari keempat pertisipan hanya satu partisipan, yakni LI yang sudah melakukan hal tersebut dalam mendampingi anak belajar di kelas.

Terdapat pola yang sama pada semua partisipan dalam menangani anak dengan kecemasan berpisah. Guru sudah melakukan perannya dalam mendampingi anak di kelas. Akan tetapi, upaya penanganan tersebut kurang tepat karena kurang didasari oleh keterampilan yang cukup. Hal ini tampak dari pemberian reward (stampel) yang tidak memenuhi prinsip-prinsip yang harus dilakukan sehingga tidak dapat membantu dalam membentuk perilaku baru yang diinginkan. Prinsip-prinsip pemberian reward menurut Irawati (2005) antara lainReward diberikan secara konsisten dan ada batasnya. Guru dalam memberikan Reward kurang konsisten yang pada akhirnya perilaku yang diinginkan tidak muncul dan menjadi sulit ketika ingin dibentuk kembali. Reward dibuat melalui kesepakatan dengan mempertimbangkan kesesuaian dengan kondisi anak. Dalam kasus diatas belum terjadi kesepakatan antara anak dan guru.Guru berinisiatif sendiri dalam menentukan reward pada anak.

Keterampilan yang kurang membuat guru merasa kesulitan. Selain keterampilan, guru kurang memiliki pengetahuan mengenai temperamen anak. Anak dalam kasus ini memiliki temperamen yang sulit yang bereaksi secara negatif, sering menangis dan cepat frustasi (Thomas \& Chess dalam Santrock, 2012). Anak-anak dengan temperamen sulit sering menangis, temper tantrum, sulit menjalin hubungan dengan orang asing serta menghindar dari pengalaman baru (Dariyo, 2007).Mengatasi anak dengan temperamen seperti ini membutuhkan beberapa pendekatan seperti yang sudah guru lakukan. Namun, pengetahuan guru yang kurang tersebut membuat pendekatan yang dilakukan belum maksimal yang membuat guru tidak hanya kesulitan namun juga kewalahan. Pada akhirnya yang dilakukan adalah pembiaran pada perilaku anak di dalam kelas dan mengandalkan figur lekat atau orang lain (helper). Guru juga menjadi kurang memberikan perhatian dan melibatkan anak pada pembelajaran di kelas.

Dari hasil wawancara ditemukan bahwa guru mengeluhkan bahwa orangtua kurang dapat bekerjasama dalam menangani kecemasan berpisah yang 
dialami anak di sekolah. Namun, di sisi lain ketika guru merasa kesulitan dan kewalahan menangani anak di kelas, guru malah cenderung membiarkan orangtua menunggui di dalam kelas bahkan mengandalkan orangtua untuk mendampingi anak selama pembelajaran berlangsung. Hal ini tentunya akan membuat anak semakin sulit untuk dipisahkan dari orangtua dan tidak menurunkan tingkat kecemasan berpisah pada anak. Guru memerlukan keterampilan dalam menghadapi wali murid. Keterampilan yang dimaksud meliputi cara memberikan pemahaman kepada orangtua tentang permasalahan yang dialami anak dan tindakan yang harus dilakukan. Guru dan orangtua haruslah sama-sama bekerja sama dalam menangani anak di sekolah.

\section{Kesimpulan Dan Saran}

Berdasarkan hasil penelitian yang sudah dilakukan menunjukkan bahwa penanganan yang dilakukan oleh guru belumlah maksimal. Hal ini terlihat dari anak masih mengalami gejala kecemasan berpisah di sekolah. Terdapat pola yang sama pada tiap-tiap guru dalam menangani anak dengan kecemasan berpisah. Guru juga sudah melakukan perannya dalam mendampingi anak di kelas. Akan tetapi, upaya penanganan tersebut kurang didasari oleh pengetahuan dan keterampilan yang cukup. Pada akhirnya guru merasa kesulitan dan kewalahan dalam mengani anak yang mengalami kecemasan berpisah di sekolah. Adapun saran yang diberikan dalam penelitian ialah sebagai berikut :

a. Pada guru :

1) Guru dapat meningkatkan pengetahuan dan keterampilan dengan mengetahui gambaran kecemasan berpisah yang dialami anak di sekolah.

2) Dalam memberi reward ke anak diharapkan lebih memperhatikan prosedur atau prinsip-prinsip yang seharusnya dilakukan.

3) Mengadakan pertemuan dengan orangtua untuk memfasilitasi dan berkolaborasi menyusun strategi mengatasi anak dengan kecemasan berpisah supaya bisa bersekolah dengan normal. 
b. Pada Orangtua :

1) Mengetahui kondisi dan gambaran anak sehingga dapat melakukan tindakan yang tepat dan sesuai di rumah.

2) Bekerjasama dengan guru di sekolah untuk mengatasi kecemasan berpisah supaya dapat meningkatkan keberfungsian anak di sekolah.

\section{DAFTAR PUSTAKA}

Albano, A.M. \& Kendall, P.C. (2002). Cognitive Behavioral Therapy for Children and Adolescents with Anxiety Disorder: Clinical Research Advances. International Review of Psychiatry.

Dabkowska, M., Araszkiewicz, A., Dabkowska, A., Wilkosc, M. (2011). Separation Anxiety in Children and Adolescents Handbook of Different Views of Anxiety Disorders.

Davison, G., Neale, J., Kring, A.M. \& Johnson, S.L. (2012). Abnormal Psychology Ed. 12. United States of America: John Wiley \& Sons, Inc.

Hanna, G.L, Fischer, D.J., Fluent, T.E. (2006). Separation Anxiety Disorder and School Refusal in Children and Adolescent. Pediatrics in Review, 56 - 63.

Hasanah, N. (2013). Terapi Token Ekonomi untuk Mengubah Perilaku Lekat di Sekolah. Jurnal Humanitas, 10(1) 1 - 18.

Irawati, I. (2005) Mendidik dengan Cinta.Jakarta : Pustaka Inti.

Kossowsky, J., Pfaltz, M.C., Schneider, S., Taeymans, J., Locher, C., Gaab, J. (2012). The Separation Anxiety Hypothesis of Panic Disorder Revisited: A Meta-Analysis. Journal of Psychiatry, 1-14.

Kozier, (2011). Buku Ajar Fundamental Keperawatan: Konsep, Proses dan Praktik Ed.7 Vol.2. Jakarta: EGC

Moldovan, O. D., Moldovan, T. (2013). The Separation Anxiety at Kindergarten Children. Journal Plus Education, 11(2) 97 - 104.

Morr, C. Schneider, S. (2013). Intensive Treatments for Separation Anxiety Disorder in Children and Adolescent.Psychopatology Review, 201-208.

Peleg, O., Halaby, E., Whaby, E. (2006). The Relationship of Maternal Separation Anxiety and Differentiation of Self to Children's Separation Anxiety and Adjustment to Kindergarten : A Study in Druze Families. Anxiety Disorders, 20973 - 995. 
Sadock, B.J., Sadock, V.A., \& Ruiz, P. (2015). Kaplan \& Sadock'sSynopsis of Psychiatry: Behavioral Sciences / Clinical Psychiatry Ed.11. Philadelphia: Wolters Kluwer.

Santrock, J.W. (2012). Life-Span Development: Perkembangan Masa-Hidup Ed.13 Jilid 1. Jakarta: Penerbit Erlangga.

Schaefer, C.E., Millman, H.L. (1981). How to Help Children with Common Problems. United States of America: Litton Education Publishing, Inc.

Scheneider, S, Rapee, R,M, Dubi, K, In-Albon, T. (2009). Forced Choice Reaction Time Paradigm in Children with Separation Anxiety Disorder, Social Phobia, and Nonanxious Controls. Behaviour Research and Therapy, $471058-1065$.

Scheneider, S., dkk. (2012). Separation Anxiety Disorder in Children : Disorder Specific Responses to Experimental Separation from The Mother. Journal of Child Psychology and Psychiatry, 53(2) 178 - 187.

Scheneider,S., Kossowsky, J., Wilhelm, F.H.. (2013). Responses to Voluntary Hyperventilation in Children with Separation Anxiety Disorder : Implication for The Link to Panic Disorder. Journal of Anxiety Disorder, 27 $627-634$.

Semiun, Y. (2006). Kesehatan Mental 3. Yogyakarta: Penerbit Kanisius

Sugiyono. (2015). Metode Penelitian \& Pengembangan: Research and Development. Bandung: Penerbit Alfabeta.

Usman, U. (2002). Menjadi Guru Profesional. Bandung: PT Remaja Rosdakarya. 